\title{
Assessment of Slope Instability and Risk Analysis of Road Cut Slopes in Lashotor Pass, Iran
}

\author{
Mohammad Hossein Taherynia, ${ }^{1}$ Mojtaba Mohammadi, ${ }^{1}$ and Rasoul Ajalloeian ${ }^{2}$ \\ ${ }^{1}$ Department of Geology, Faculty of Science, Kharazmi University, Karaj 31979-37551, Iran \\ ${ }^{2}$ Department of Geology, Faculty of Science, University of Isfahan, Isfahan 81746-73441, Iran \\ Correspondence should be addressed to Mohammad Hossein Taherynia; mh.taherynia@gmail.com
}

Received 14 October 2013; Accepted 12 February 2014; Published 10 April 2014

Academic Editor: Agust Gudmundsson

Copyright (c) 2014 Mohammad Hossein Taherynia et al. This is an open access article distributed under the Creative Commons Attribution License, which permits unrestricted use, distribution, and reproduction in any medium, provided the original work is properly cited.

\begin{abstract}
Assessment of the stability of natural and artificial rock slopes is an important topic in the rock mechanics sciences. One of the most widely used methods for this purpose is the classification of the slope rock mass. In the recent decades, several rock slope classification systems are presented by many researchers. Each one of these rock mass classification systems uses different parameters and rating systems. These differences are due to the diversity of affecting parameters and the degree of influence on the rock slope stability. Another important point in rock slope stability is appraisal hazard and risk analysis. In the risk analysis, the degree of danger of rock slope instability is determined. The Lashotor pass is located in the Shiraz-Isfahan highway in Iran. Field surveys indicate that there are high potentialities of instability in the road cut slopes of the Lashotor pass. In the current paper, the stability of the rock slopes in the Lashotor pass is studied comprehensively with different classification methods. For risk analyses, we estimated dangerous area by use of the RocFall software. Furthermore, the dangers of falling rocks for the vehicles passing the Lashotor pass are estimated according to rockfall hazard rating system.
\end{abstract}

\section{Introduction}

Appraisal hazard and risk analysis is one of the most important issues in the rock slopes instability study. Risk is a measure of the probability and severity of adverse effects [1]. Risk is the combination of probability of an event and its consequences [2]. Therefore, for risk analysis of slope instability, the first step is assessment of the slope instability potential and probability of occurrence of the slope failure, and the next step is determination of the consequence and degree of danger of the slope instability.

Rock mass classification is a useful means for the assessment of the instability potentialof rock cut slopes based on the most important inherent and structural parameters [3]. The geomechanics classification or the rock mass rating (RMR) introduced by Bieniawski [4] was the first attempt to assess rock slope instability based on rock mass classification. Romana [5], by developing RMR, proposed slope mass rating (SMR) classification system, especially for rock slopes classification and judgment about slopes stability. Slope stability rating (SSR) system is proposed by Taheri and Tani $[6,7]$ for the characterization of slope stability of heavily jointed rock masses. This system is based on the geological strength index (GSI) system and the nonlinear Hoek-Brown failure criterion. To provide a more quantitative numerical basis for evaluating the GSI, this classification system was modified by Sonmez and Ulusay [8] and Sonmez and Ulusay [9] in which latest version of the quantitative GSI chart is used in the SSR system. Since some of the major slope stability parameters are not included in GSI, in SSR systems, besides the geological strength index (GSI), five additional parameters have been taken into account. These additional parameters included the uniaxial compressive strength, rock type, slope excavation method, groundwater, and earthquake force.

The RQD parameter is not used in the SSR calcification systems. This is the most advantage of the SSR comparing to the SMR and other calcification systems (SRMR, CSMR, GSI, VRFSR, and FRHI). The RQD is a basic component of many rock mass classification systems. There are several major disadvantages related to RQD definition and the 
drilling procedure [3]. Furthermore, in the RMR and SMR classification systems are simultaneously used the RQD index and "discontinuity spacing" parameter. In fact, the spacing of discontinuities has double influence on the final rating [10]. The other advantage of SSR classification is taken into account: the effect of earthquake force on the slope instability. This is very important and essential for slopes stability analyses in seismic active zones. Iran is located in the Alpine-Himalayan orogenic system and shows high seismic activity.

In many cases, spatially in vertical slopes or very steep slopes such as cut slope, other types of rock slope failure (wedge failure, planer failure, and toppling) may eventually lead to the rockfall event. If sliding distance of rock block or rock mass that detached by sliding, toppling, or falling was negligible to descending distance through air, it is defined as a rockfall [11]. Rockfalls constitute a major hazard in rock cuts alongside roads in mountainous regions that causes loss of life and property because of its very rapid movement [12].

In the past, the rockfall simulation was based on experience and extensive in situ rockfall tests [13]. Ritchie [14] by carrying out full scale tests on rockfall event proposed simple chart for determining required width and depth of rock catch ditches in relation to height and slope angle. Over the last decades, many computer programs are developed for simulation of rockfall [15-18]. One of the most practical programs of these computer programs is the RocFall software that can be used to simulate almost all types of rockfall events [19]. This software provides valuable information about kinetic energy, velocity, bounce height, and fall-out distance of falling rock fragment that are essential to determine the consequence and degree of danger of slope instability. The RocFall software also can be used to design remedial measures and test their effectiveness [19].

At the last two decades, a number of slope instability risk assessment systems have been developed and rockfall hazard rating system [20] is one of the most well-known of these systems [21]. This method used a simple approach for assessing and quantifying the risk of rockfalls in the transportation routes [22]. The rockfall hazard rating system (RHRS) contains nine deferent parameters which can be divided into two groups: the parameters that define rockfall hazard (slope height, geologic character, volume of rockfall/block size, climate, and presence of water on slope and rockfall history) and the parameters that indicate the vehicle vulnerability (ditch effectiveness, average vehicle risk, percent of decision sight distance, and roadway width) [12].

In this research, at the first step, the instability potential of the Lashotor trenches was assessed by use of SMR and SSR classification systems. Rock mass classifications indicate high instability potential and likely rockfalls in the Lashotor cut slopes. Therefore, direction, speed, and energy of the falling rock fragments are simulated for risk analyses using the RocFall software. Finally, the risk of falling rocks for the vehicles passing the Lashotor pass is estimated by using the rockfall hazard rating system.

\section{General Characteristics of the Study Area}

The Lashotor pass was constructed at 1991 in distance of $22 \mathrm{~km}$ of the Isfahan-Shiraz highway in Iran to eliminate the inappropriate and dangerous curvatures in the Lashotor pass and shorten the path. As shown in Figure 1, the length of the previous way is $6.88 \mathrm{~km}$, while the current path in the Lashotor pass is $3.62 \mathrm{~km}$. Also the new road is straighter than the previous one. Generally, this pass has 250 meters length and 24 meters width. The maximum height of the walls is 34 meters and the dips of the cut slopes are about 80 degrees.

Geologically, the Lashotor pass is located in the KolahGhazi region in the central part of the Sanandaj-Sirjan zone. In this region, 30 to 50 meters of the upper Cretaceous limestone is lying on the lower Cretaceous shale and marl layers. In the central part of the Sanandaj-Sirjan zone, the fault pattern consists of major NW-trending longitudinal faults, NE-SW-trending transverse faults, and N-S-trending oblique faults [23]. Fault pattern in the study area is shown in Figure 2.

The nearest fault to the Lashotor pass is the KolahGhazi fault. This fault has several branch minor faults. Approximately $61 \mathrm{~m}$ offset occurs along the Kolah-Ghazi fault, where the Quaternary gravel plains and the Holocene alluvial deposits are dissected and dextrally displaced by the fault and its branching minor faults. The maximum value of the slip rate calculated along the Kolah-Ghazi fault is about $9.2 \mathrm{~mm} /$ year [23]. Figures 3 and 4 show general view of the eastern and western Lashotor cut slopes. The movement caused by fault in the eastern cut slope face is indicated in Figure 3. Figure 4 shows a branch fault of the Kolah-Ghazi fault in the southern part of the Lashotor pass.

The presence of tectonic structures, such as faults and folds, can play significant role in the slope instability [24]. According to Pourghasemi et al. [25] there is high instability probability of slopes in distance less than $100 \mathrm{~m}$ of faults. KhaloKakaie and Naghadehi [26] studied slope stability with use of interaction matrix and estimated proportional share of sixteen parameters in slope failure. According to these studies, presence of faults and folds played significant role in the slope failure and its proportional share in slope failure is about $7.75 \%$.

Figure 4 shows an unstable rock wedge in the western slope that is formed by intersection of the joint sets. These are just a few of evidences which address the instability of cut slopes in the Lashotor pass. The most notable failure in this pass occurred during a construction which caused temporary cessation of excavation [27]. The failed part of the western slope is shown in Figure 5.

\section{Assessment of Instability Potential and Failure Types of the Slopes}

For assessing of instability potential and failure types, at the first step, discontinuity and their spatial orientations in the Lashotor slopes were studied. According to the strike and dip of the discontinuity in respect to slope face orientation, we 

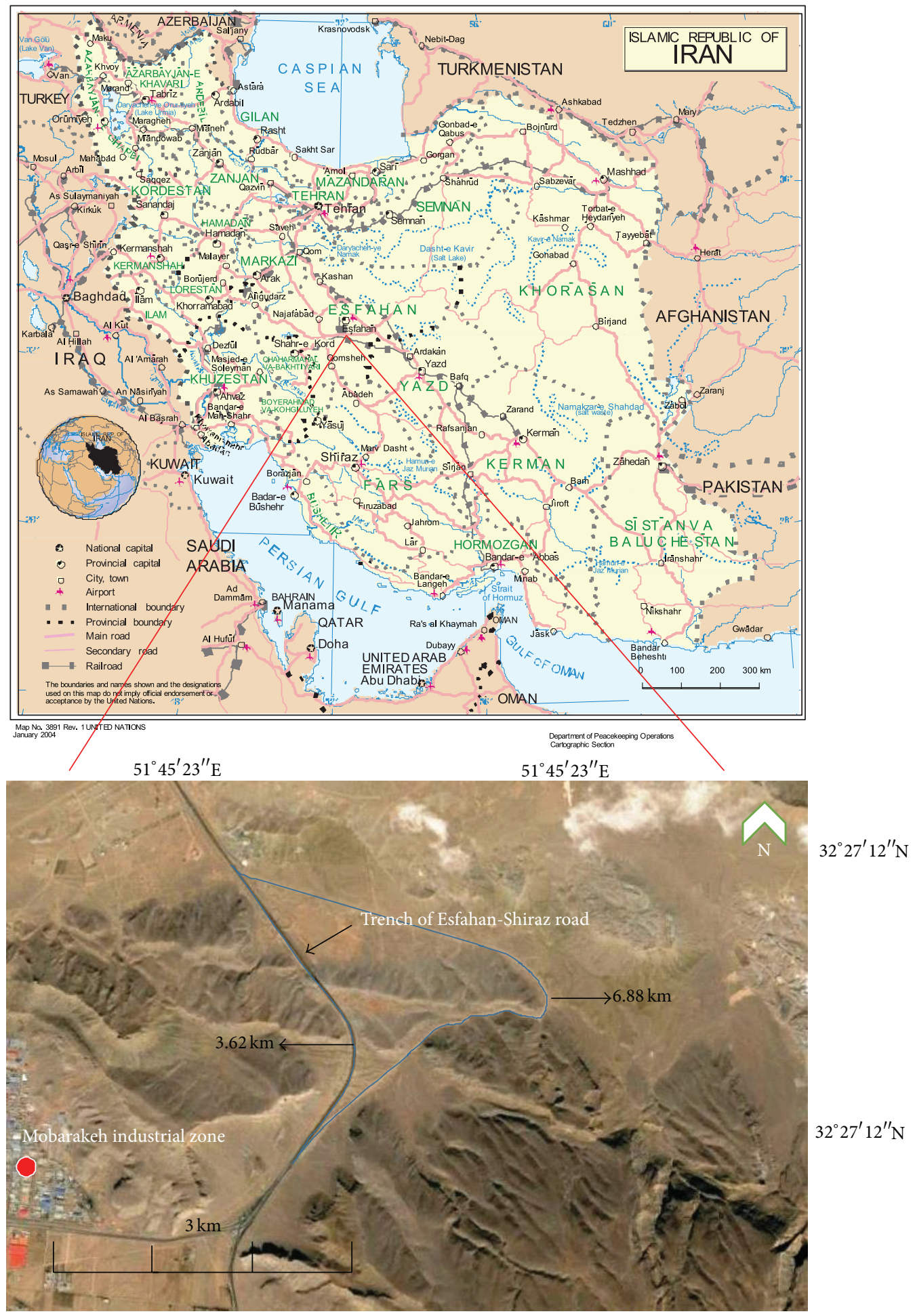

FIGURE 1: The pervious and current roads are shown in the Google Earth image.

can determine the probability and type of failure. Properties and orientation of joints sets and bedding plane in the two walls of the Lashotor pass are determined in a field survey. A total of 253 discontinuities were surveyed.

Most of the joints have rough surfaces and calcite filling. Deduced information from the field joints study has been analyzed by using Dips and Swedge software, whose results are presented in Figures 6 and 7.

As shown in Figures 6 and 7, there are five discontinuities sets (four joint sets and bedding surface) in both walls of the Lashotor pass, in which intersection of the joint sets formed different unstable wedges in eastern and western walls. 
TABLE 1: Value of $\mathrm{RMR}_{\mathrm{B}}$ in the two slopes of the Lashotor pass.

\begin{tabular}{lcccc}
\hline \multirow{2}{*}{ Parameters } & \multicolumn{2}{c}{ Western cut slope } & \multicolumn{2}{c}{ Eastern cut slope } \\
& Value & Rating & Value & Rating \\
\hline UCS & $4.2 \mathrm{MPa}$ & 12 & $4.2 \mathrm{MPa}$ & 12 \\
RQD & $88 \%$ & 17 & $89 \%$ & 17 \\
Joint spacing & $1.3 \mathrm{~m}$ & 15 & $0.6 \mathrm{~m}$ & 10 \\
Joint condition & Slicken sided and $1-5 \mathrm{~mm}$ wide & 10 & Slicken sided and 1-5 mm wide & 10 \\
Ground water condition & Damp & 10 & Damp & 10 \\
Summation $\left(\mathrm{RMR}_{\mathrm{B}}\right)$ & & 64 & 59 \\
\hline
\end{tabular}

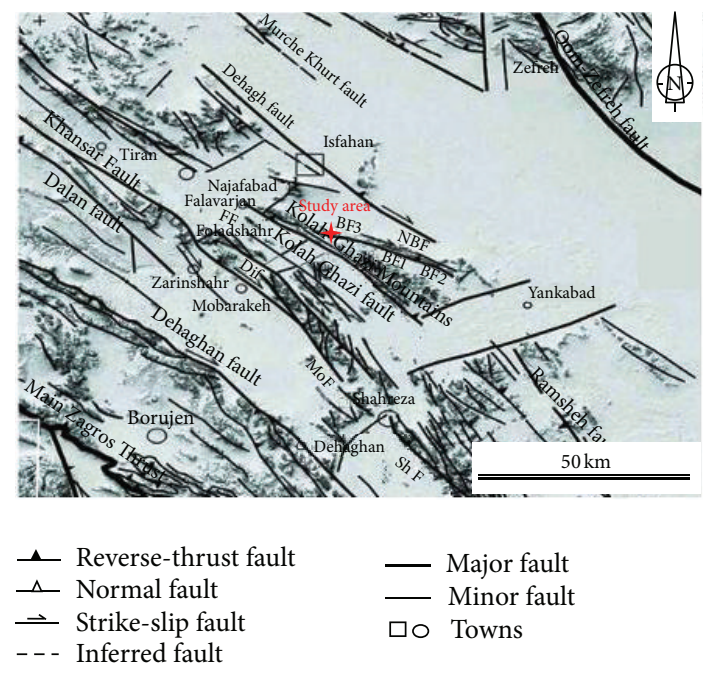

FIgURE 2: Fault pattern in the Kolah-Ghazi region [23].

3.1. Slope Mass Rating (SMR) Classification. One of the most common classification systems for evaluation of rock slope stability is the SMR classification. The slope mass rating $(\mathrm{SMR})$ is obtained from basic rock mass rating $\left(\mathrm{RMR}_{\mathrm{B}}\right)$ by adding adjustment factors depending on the relative orientation of joints and slope and adding another factor depending on the method of excavation based on (1) as follows [28]:

$$
\mathrm{SMR}=\mathrm{RMR}_{\mathrm{B}}-(F 1 \cdot F 2 \cdot F 3)+F 4,
$$

where the $\mathrm{RMR}_{\mathrm{B}}$ is computed according to Bieniawski's [4] proposal, $F 1, F 2$, and $F 3$ are adjustment factors that are related to joints orientation with respect to slope orientation, and F4 is the correction factor depending on the excavation method of slope.

Table 1 shows the required parameters for determination of $\mathrm{RMR}_{\mathrm{B}}$ and their rating for two walls of the Lashotor pass.

Adjustment factors of $F 1, F 2$, and $F 3$ for each probability slide plane or slide line are evaluated separately and their results are presented in Tables 2 and 3.

Finally, after determination of $\mathrm{RMR}_{\mathrm{B}}$ and adjustment factors for most critical state, values of modified SMR for the two walls are calculated and presented in Table 4.

The slope excavation method is a normal blasting. Therefore, factor of F4 is zero.

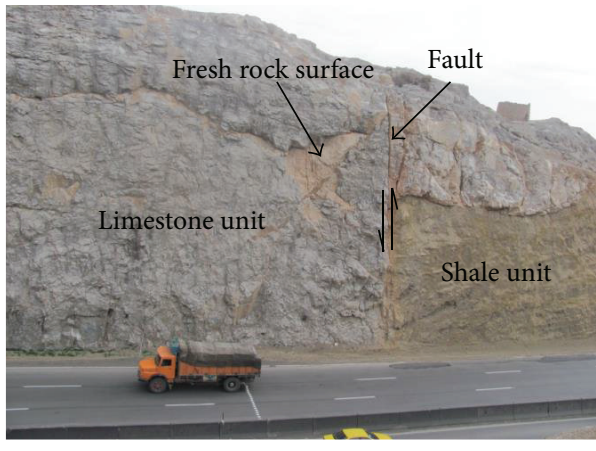

FIGURE 3: A general view of the eastern slope: rock unit, fresh rock surface, and displacement of fault are shown.

TABle 2: Adjustment factors $(F 1, F 2$, and $F 3)$ of the western cut slope.

\begin{tabular}{lcccc}
\hline & $F 1$ & $F 2$ & $F 3$ & $F 1 \cdot F 2 \cdot F 3$ \\
\hline $\mathrm{J} 1$ & 0.15 & 1 & -25 & -3.8 \\
$\mathrm{~J} 2$ & 0.15 & 1 & -25 & -3.8 \\
$\mathrm{~J} 3$ & 0.33 & 1 & -25 & -8.25 \\
$\mathrm{~J} 4$ & 0.52 & 1 & -25 & -13 \\
Sliding line resulting & 0.55 & 1 & -60 & -33 \\
intersection of J1 and J2 & & & & -5.4 \\
Bedding plane & 0.6 & 0.15 & -60 & - \\
\hline
\end{tabular}

The sum adjustment factors for the wedge failure are more than other types of failure. Therefore, it is concluded that wedge failure type is more critical than others in both walls of the Lashotor pass and should be considered as a worst state with lowest SMR rate.

Based on the SMR classification system, the rock mass in the two slopes of the Lashotor pass is in the bad class (IV) and they are unstable and a big wedge failure is feasible (Probability of Failure 60\%).

3.2. Slope Stability Rating (SSR) Classification. A lot of excavated slopes in Iran and Australia were studied by Taheri and Tani [6]. Based on this investigation, they presented the slope stability rating (SSR) classification system as follows:

$$
\mathrm{SSR}=\mathrm{GSI}_{(2002)}+(F 1+F 2+F 3+F 4+F 5),
$$




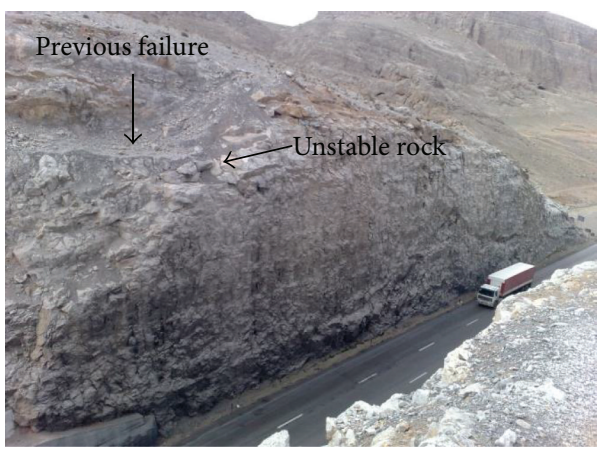

(a)

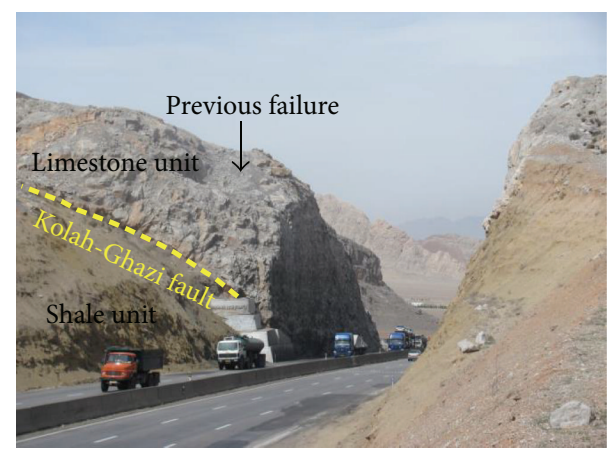

(b)

FIGURE 4: Two views of the western slope: rock unit, Kolah-Ghazi fault branch, unstable rock blocks, and traces of previous slope failure are shown.

TABLE 3: Adjustment factors $(F 1, F 2$, and F3) of the eastern cut slope.

\begin{tabular}{lcccc}
\hline & $F 1$ & $F 2$ & $F 3$ & $F 1 \cdot F 2 \cdot F 3$ \\
\hline $\mathrm{J} 1$ & 0.15 & 1 & -25 & -3.8 \\
$\mathrm{~J} 2$ & 0.15 & 1 & -25 & -3.8 \\
$\mathrm{~J} 3$ & 0.30 & 1 & -25 & -7.5 \\
$\mathrm{~J} 4$ & 0.58 & 1 & -25 & -14.5 \\
Sliding line resulting & 0.68 & 1 & -50 & -34 \\
$\begin{array}{l}\text { intersection of J2 and J3 } \\
\text { Bedding plane }\end{array}$ & 0.6 & 0.15 & -60 & -5.4 \\
\hline
\end{tabular}

TABLE 4: SMR values.

\begin{tabular}{lccc}
\hline & $\mathrm{RMR}_{\mathrm{B}}$ & $F 1 \cdot F 2 \cdot F 3+F 4$ & $\mathrm{SMR}$ \\
\hline Western cut slope & 64 & -33 & 31 \\
Eastern cut slope & 59 & -34 & 25 \\
\hline
\end{tabular}

where GSI ${ }_{(2002)}$ is modified GSI by Sonmez and Ulusay (2002) and $F 1, F 2, F 3, F 4$, and $F 5$ are adjustment factors whose explanation and rating are presented in Table 5.

3.2.1. Determination of $G S I_{(2002)}$. To determine the GSI using modified chart of Sönmez and Ulusay [9], quantitative GSI chart, two parameters of surface conditions rating (SCR) and structural rating (SR) must be determined as follows:

$$
\begin{gathered}
\mathrm{SCR}=R_{r}+R_{w}+R_{F}, \\
\mathrm{SR}=-17.5 \ln \left(J_{V}\right)+79.8,
\end{gathered}
$$

where $R_{r}, R_{w}$, and $R_{f}$ are roughness rating, weathering rating, and infilling rating, respectively, and $J_{V}$ is the number of joints per unit volume of rock mass. Rating of these parameters and the SCR value are presented in Table 6.

The number of joints within unit volume of rock mass $\left(J_{V}\right)$ is calculated using the following equation:

$$
J_{V}=\sum_{i=1}^{j} \frac{1}{S_{i}}
$$

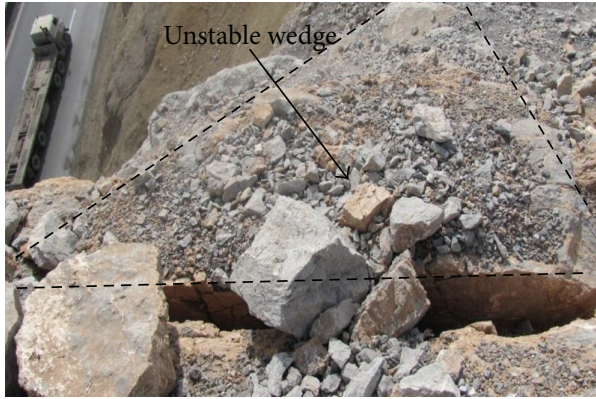

FIGURE 5: The rock wedge prone to sliding in the west cut slope of the Lashotor pass.

where $S_{i}$ is the average joint spacing in meters for the $i$ th joint set and $j$ is the total number of joint sets except the random joint set.

In the studied slopes $J_{V}=8$ and SR value with use of (4) was equal to 43 .

Using two parameters SCR and SR, GSI value of the slopes rock mass was determined to be about 55 .

3.2.2. Determination of Adjustment Factors F1, F2, F3, F4, and F5. F1: the intact rock strength, UCS, is one of the effective parameters on the stability of rock slopes. Point load test was done on approximately cubic shape samples. The point load index was determined to be about 4.2 and the uniaxial comparative strength of the samples were estimated using the point load index in the range of 50 to $100 \mathrm{Mpa}$. Therefore, the rate of $F 1$ according to Table 5 is equal to 28 .

F2: slope stability analyses showed that the variation of $m_{i}$ in the Hoek-Brown failure criterion and the dry unit weight of intact rock have considerable effects on the stability of rock slopes. Since these two parameters are related to rock type (lithology) of slope, Taheri and Tani [6], with the use of the reference tables of rock material specifications proposed by Hoek et al. [36], classified rocks into six groups with different lithological characteristics (Table 6). As mentioned above lithology of the rock mass of the slopes is carbonate and shale, which, according to Table 5, are in Group 3 and their rates are equal to 9 . 


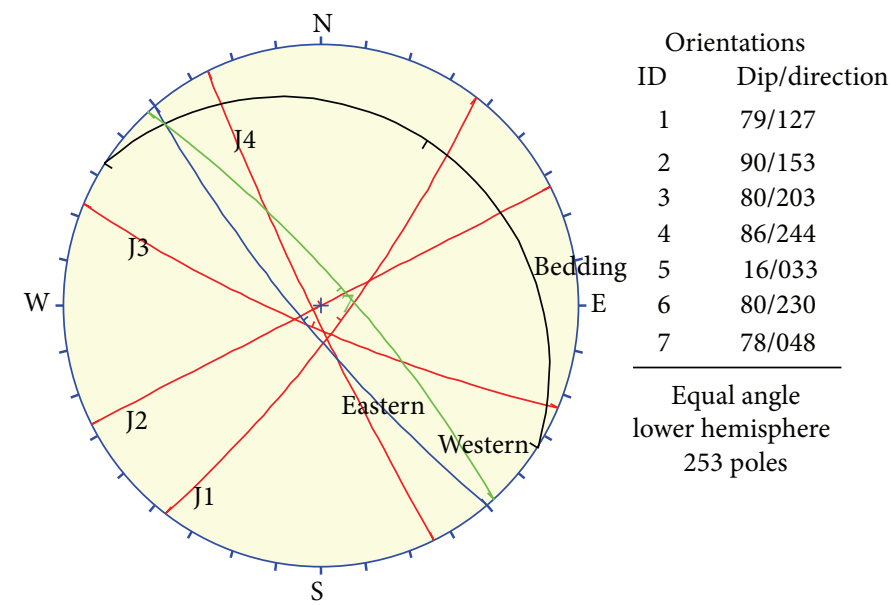

FIGURE 6: The stereographic projection of joints sets and bedding in the western and eastern slope of the Lashotor pass.

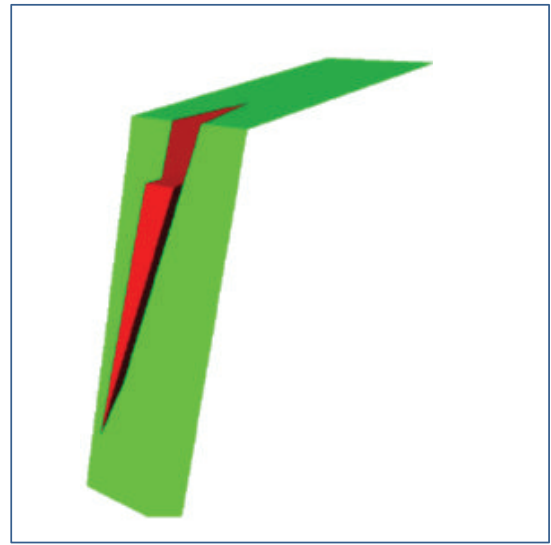

(a)

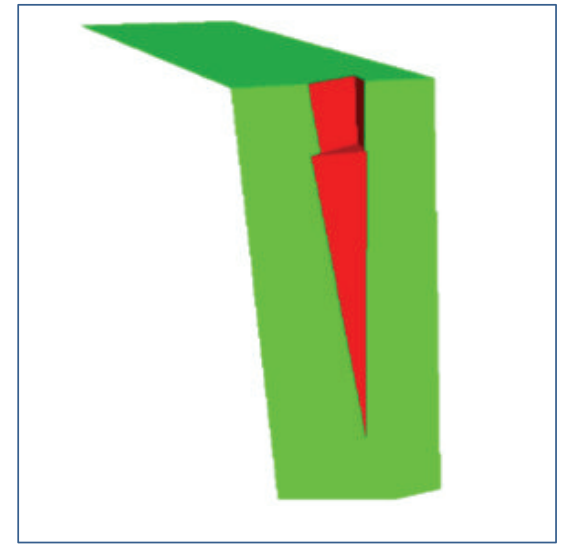

(b)

FIgURE 7: (a) Three-dimensional view of the sliding wedge which forms the intersection of the joints J1 and J2 and the western slope face. (b) Three-dimensional view of the sliding wedge which forms the intersection of the joints $\mathrm{J} 2$ and $\mathrm{J} 3$ and the eastern slope face.

TABLE 5: Adjustment factors F1, F2, F3, F4, and F5 and range of value in the SSR classification system (Taheri and Tani 2010) [6].

\begin{tabular}{|c|c|c|c|c|c|c|c|c|}
\hline \multirow{2}{*}{$F 1$} & \multirow{2}{*}{$\begin{array}{l}\text { Parameter } \\
\text { Uniaxial compressive } \\
\text { strength }(\mathrm{MPa})\end{array}$} & \multicolumn{3}{|c|}{ Range of values } & \multirow[b]{2}{*}{$25-50$} & \multirow[b]{2}{*}{$50-100$} & \multirow[b]{2}{*}{$100-150$} & \multirow[b]{2}{*}{$150-200$} \\
\hline & & & $0-10$ & $10-25$ & & & & \\
\hline & Rating & & 0 & 7 & 18 & 28 & 37 & 43 \\
\hline \multirow{2}{*}{$F 2$} & Rock type & & Group 1 & Group 2 & Group 3 & Group 4 & Group 5 & Group 6 \\
\hline & Rating & & 0 & 4 & 9 & 17 & 20 & 25 \\
\hline \multirow{2}{*}{ F3 } & Slope excavation method & & Waste damp & Poor blasting & Normal blastir & Smooth blasting & Presplitting & Natural slope \\
\hline & Rating & & -11 & -4 & 0 & 6 & 10 & 24 \\
\hline \multirow[t]{2}{*}{ F4 } & Groundwater & $\begin{array}{l}\text { (Groundwater } \\
\text { level from bottom } \\
\text { of the slope/slope } \\
\text { height) } \times 100\end{array}$ & Dry & $0-20 \%$ & $20-40 \%$ & $40-60 \%$ & $60-80 \%$ & $80-100 \%$ \\
\hline & Rating & & 0 & -1 & -3 & -6 & -14 & -18 \\
\hline \multirow[t]{2}{*}{ F5 } & Earthquake force & $\begin{array}{l}\text { Horizontal } \\
\text { acceleration }\end{array}$ & 0 & $0.15 \mathrm{~g}$ & $0.20 \mathrm{~g}$ & $0.25 \mathrm{~g}$ & $0.30 \mathrm{~g}$ & $0.35 \mathrm{~g}$ \\
\hline & Rating & & 0 & -11 & -15 & -19 & -22 & -26 \\
\hline
\end{tabular}




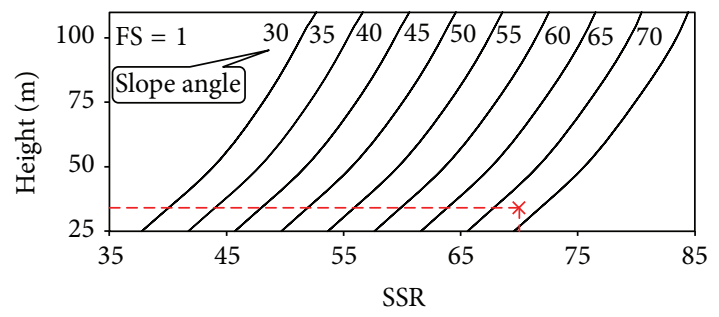

FIGURE 8: Determination of stable dip of rock slope based on SSR value and slope's height.

TABLE 6: Joints surface condition rating (SCR) and its rating in the studied slopes according to modified GSI classification [9].

\begin{tabular}{lcccc}
\hline & Roughness & Weathering & Infilling & $\begin{array}{c}\text { SCR } \\
\text { (mean) }\end{array}$ \\
\hline Description & Rough-very rough & None_slightly & Hard & - \\
Rating & $5-6$ & $5-6$ & $2-4$ & 14 \\
\hline
\end{tabular}

F3: the slope excavation method has considerable effects on the stability of rock slopes. The conventional excavation methods and their rates are presented in Table 5. As previously mentioned, excavation method of the Lashotor pass is normal blasting and, according to Table $5, F 3=0$.

F4: since the groundwater level is below the bottom of the pass, rate of this parameter $(F 4)$ according to Table 5 is equal to zero.

F5: the dynamic loading of earthquake has great effects on instability of slopes and should account for slope stability analysis especially in active seismic zones. Based on the seismic hazard zonation map of Iran for the return period of 75 years [37], the Lashotor pass is located in the low risk zone with the horizontal ground acceleration of about $0.2 \mathrm{~g}$.

In detailed study, the amount of horizontal earthquake acceleration for studied area can be calculated using the relationship between the distance of the site to the hypocenter of earthquakes and earthquakes magnitude.

Also various relations are proposed by many researchers for any regions to determine the magnitude of earthquakes in terms of the length of causative fault. The most widely used of these relations for Iran are presented by MohajerAshjai and Nowroozi [31], Nowroozi [29], and Ambraseys and Melville [30]. Major faults at the study area and other required parameters to calculate the maximum earthquake magnitude and horizontal peak ground acceleration (PGA) are presented in Table 7. The results of calculations of the maximum earthquake magnitude and PGA for the major faults around the Lashotor pass are presented in Table 8.

Based on the results of the calculations, the predicted maximum ground horizontal acceleration for the study area is equal to $0.3 \mathrm{~g}$, which is generated by the Dehagh fault (DeF). Therefore, rate of F5 according to Table 5 is determined to be equal to -22 .

3.2.3. Calculation of SSR and the Slope Stability Assessment. The value of slope stability rating (SSR) of two walls of the Lashotor pass was determined to be about 70. Due to the lack of orientation effect of discontinuities with respect to slope orientation in SSR value, the value of SSR is the same for both sides of the Lashotor pass.

Taheri and Tani [6] presented several graphs with the different safety factor for judgments about slope stability based on height and dip of the slope and its SSR value. By plotting of the SSR value versus the slopes height in these graphs (Figure 8), it was found that the dip of the studied slopes (approximately $80^{\circ}$ ) was higher than the maximum stable dips (nearly $65^{\circ}$ ). Therefore, to achieve stable slopes, with the minimum acceptable safety factors (FS $=1$ ), the dips angle of slopes should be reduced to less than $67^{\circ}$.

\section{Rockfall Simulation Analysis}

An essential component in the evaluation of potential hazard of rock slope instability is simulation of rockfalls to estimate the rock falling trajectories, translational velocity, total kinetic energy, and endpoints location of the falling rocks. RocFall software is a $2 \mathrm{D}$ statistical analysis program for rockfall simulation. In this paper, RocFall ${ }^{\odot} \mathrm{V} 4$ software [38] was used for modeling of rockfalls in the Lashotor pass. Rockfall simulation in the Lashotor pass in Figure 9 indicated that most of the falling rocks will reach the highway.

As it is shown in Figure 10, falling rock have high velocity which exceeded $20 \mathrm{~m} / \mathrm{s}$ in the moment of impact with the surface of highway.

\section{Falling Rock Hazard}

One of the most accepted methods for rockfall hazard assessment in highway is the rockfall hazard rating system (RHRS) developed by Pierson et al. [35]. Table 9 gives included parameters and typical scores in this classification system. Also, the scores of each parameter $(y)$ can be determined by $y=3^{x}$, where $x$ for different parameter is calculated by

Slope height

$$
x=\frac{\text { slope height (feet) }}{25},
$$

Average vehicle risk

$$
x=\frac{\text { \%time }}{25},
$$

Decision Sight distance (\%)

$$
x=\frac{(120-\% \text { Decision sight distance })}{20},
$$

Roadway width

$$
x=\frac{(52-\text { Roadway width }(\text { feet }))}{8},
$$

Block size

$$
x=\text { Block size (feet), }
$$

Volume

$$
x=\frac{\text { Volume (cu.ft.) }}{3} .
$$




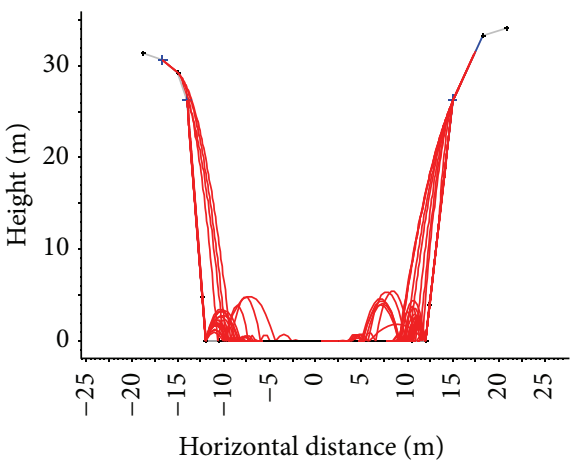

(a)

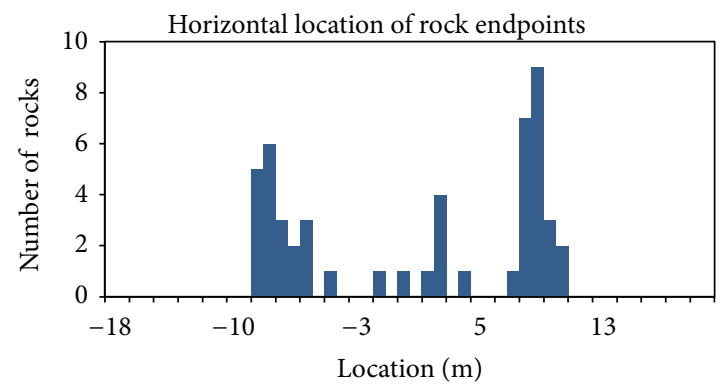

(b)

FIGURE 9: (a) Slopes geometry and trajectories. (b) Endpoints graph of falling rock fragments.

TABLE 7: Major faults at around of the Lashotor pass.

\begin{tabular}{|c|c|c|c|c|}
\hline Name of fault & Strike/dip and dip direction of fault & Length $(\mathrm{km})$ & Mechanism & Horizontal distance $(\mathrm{km})$ \\
\hline North Baharestan (NBF) & 095-115/60e75 SW & 45 & $\mathrm{D}+\mathrm{R}$ & 6.7 \\
\hline Baharestan (BF) & $280-300 / 45 \mathrm{NE}$ & 33 & $\mathrm{R}+\mathrm{D}$ & 2.4 \\
\hline Dalan (DaF) & $290-320 / 60 \mathrm{NE}$ & 180 & $\mathrm{R}+\mathrm{D}$ & 51 \\
\hline Mobarakeh (MoF) & $310-325 / 70 \mathrm{NE}$ & 60 & $\mathrm{R}+\mathrm{D}$ & 21 \\
\hline Dizicheh (DiF) & $310-335 / 75 e 80 \mathrm{NE}$ & 37 & $\mathrm{R}+\mathrm{D}$ & 19 \\
\hline Dehaghan (DF) & $120-145 / 60 \mathrm{SW}$ & 250 & $\mathrm{R}+\mathrm{D}$ & 56 \\
\hline Dehagh (DeF) & $290-320 / 60 e 70 \mathrm{NE}$ & 200 & $\mathrm{R}+\mathrm{D}$ & 16 \\
\hline Kolah-Ghazi (KGF) & $300-310 / 55 \mathrm{NE}$ & 50 & $\mathrm{R}+\mathrm{D}$ & 0 \\
\hline Foladshahr (FF) & $120-145 / 70$ SW & 70 & $\mathrm{R}+\mathrm{D}$ & 11 \\
\hline
\end{tabular}

$\mathrm{N}$ : normal, R: reverse, D: dextral, and S: sinistral strike-slip component of movements.

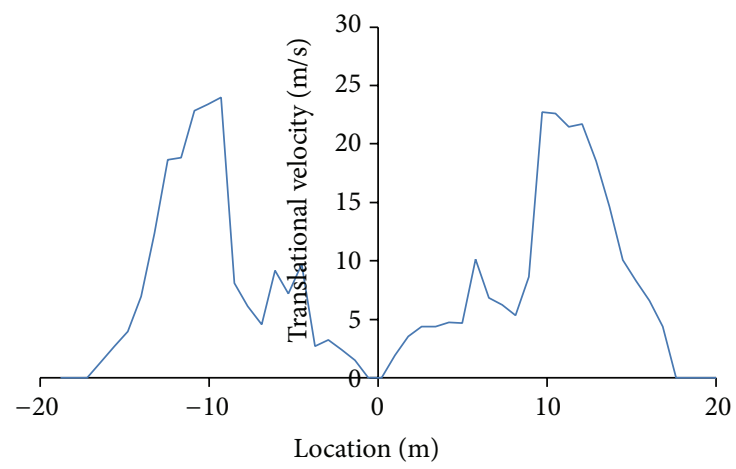

Figure 10: Translational velocity envelope of rockfalls.

(1) Slope height (m): vertical height of the slope has great effect on the energy and velocity of filling rocks. Height of the Lashotor slopes is about 34 meters. One of the factors which can be very hazardous rockfall event in the Lashotor pass is the height of the slopes.

(2) Ditch effectiveness: the effectiveness of a ditch is measured by its ability to prevent falling rock from reaching the roadway [39].

As is shown in Figures 3 and 4, the highway has no ditch. Therefore, the rating of this category was assumed to be equal to 81 .
(3) Average vehicle risk (AVR): this parameter defined percentage of time that a vehicle will be at risk and calculated as [20]

$$
\mathrm{AVR} \%=\frac{(\mathrm{ADT} / 24) \times \text { Slope length }}{\text { Posted speed limit }} \times 100 \text {, }
$$

where ADT is the average traffic per day (vehicle/day).

Posted speed limit in this section of highway equals $120 \mathrm{~km} / \mathrm{h}$ and the slope length is about $250 \mathrm{~m}$. With respect to importance of the Shiraz-Isfahan highway, this highway has heavy traffic. Therefore, at most of the time more than one vehicle is presented within the Lashotor pass (AVR > 100\%).

(4) Percent of decision sight distance: this parameter is dependent on two items: (1) the length of roadway that drivers need to make instantaneous decision which is function of posted speed limit through the rockfall section and (2) actual sight distance that is defined as shortest distance along a roadway that a six-inch object is continuously visible to a driver.

Percent of decision sight distance can be calculated as follows [20]:

$$
\mathrm{DSD} \%=\frac{\text { Actual sight distance }}{\text { decision sight distance }} \times 100 \text {. }
$$


TABLE 8: Maximum potentiality earthquakes magnitude of faults and maximum horizontal acceleration in the study area.

\begin{tabular}{|c|c|c|c|c|c|c|c|c|}
\hline Fault & $\begin{array}{c}\text { Nowroozi } \\
{[29]} \\
\end{array}$ & $\begin{array}{c}\text { Ambraseys and } \\
\text { Melville [30] }\end{array}$ & $\begin{array}{c}\text { Mohajer-Ashjai } \\
\text { and Nowroozi [31] }\end{array}$ & Mean & $\begin{array}{l}\text { Dams and } \\
\text { Moore [32] }\end{array}$ & $\begin{array}{c}\text { Niazi and } \\
\text { Bozorgnia [33] }\end{array}$ & $\begin{array}{c}\text { Zare et al. } \\
{[34]}\end{array}$ & PGA \\
\hline $\mathrm{NBF}$ & 6.7 & 6.6 & 6.8 & 6.7 & 0.39 & 0.16 & 0.16 & 0.24 \\
\hline $\mathrm{BF}$ & 6.5 & 6.4 & 6.6 & 6.5 & 0.37 & 0.14 & 0.15 & 0.22 \\
\hline $\mathrm{DaF}$ & 7.3 & 7.3 & 7.3 & 7.3 & 0.24 & 0.13 & 0.08 & 0.15 \\
\hline $\mathrm{MoF}$ & 6.8 & 6.7 & 6.9 & 6.8 & 0.32 & 0.13 & 0.11 & 0.19 \\
\hline $\mathrm{DiF}$ & 6.6 & 6.4 & 6.7 & 6.57 & 0.29 & 0.11 & 0.1 & 0.17 \\
\hline DF & 7.3 & 7.3 & 7.3 & 7.3 & 0.26 & 0.15 & 0.07 & 0.14 \\
\hline DeF & 7.3 & 7.3 & 7.3 & 7.3 & 0.51 & 0.24 & 0.21 & 0.3 \\
\hline KGF & 6.7 & 6.6 & 6.8 & 6.7 & 0.41 & 0.16 & 0.18 & 0.25 \\
\hline $\mathrm{FF}$ & 6.9 & 6.8 & 6.9 & 6.87 & 0.41 & 0.17 & 0.17 & 0.25 \\
\hline
\end{tabular}

TABLE 9: Rockfall hazard rating system parameters and their scores [35].

\begin{tabular}{|c|c|c|c|c|}
\hline \multirow{2}{*}{ Category } & \multicolumn{3}{|c|}{ Rating criteria and score } & \multirow[b]{2}{*}{ Points 81} \\
\hline & Points 3 & Points 9 & Points 27 & \\
\hline Slope height & $7.5 \mathrm{~m}$ & $15 \mathrm{~m}$ & $22.5 \mathrm{~m}$ & $30 \mathrm{~m}$ \\
\hline Ditch effectiveness & Good catchment & Moderate catchment & Limited catchment & No catchment \\
\hline Average vehicle risk (\% of time) & $25 \%$ & $50 \%$ & $75 \%$ & $100 \%$ \\
\hline $\begin{array}{l}\text { Percent of decision sight } \\
\text { distance }\end{array}$ & $\begin{array}{l}\text { Adequate sight distance, } \\
100 \% \text { of low design value }\end{array}$ & $\begin{array}{l}\text { Moderate sight } \\
\text { distance, } 80 \% \text { of low } \\
\text { design value }\end{array}$ & $\begin{array}{l}\text { Limited sight distance, } \\
60 \% \text { of low design value }\end{array}$ & $\begin{array}{l}\text { Very limited sight } \\
\text { distance, } 40 \% \text { of low } \\
\text { design value }\end{array}$ \\
\hline $\begin{array}{l}\text { Roadway width included paved } \\
\text { shoulders }\end{array}$ & $13.20 \mathrm{~m}$ & $10.80 \mathrm{~m}$ & $8.40 \mathrm{~m}$ & $6.00 \mathrm{~m}$ \\
\hline \multicolumn{5}{|l|}{ Geologic character } \\
\hline \multicolumn{5}{|l|}{ Case 1} \\
\hline Structural condition & $\begin{array}{l}\text { Discontinuous joints, } \\
\text { favorable orientation }\end{array}$ & $\begin{array}{l}\text { Discontinuous joints, } \\
\text { random orientation }\end{array}$ & $\begin{array}{l}\text { Discontinuous joints, } \\
\text { adverse orientation }\end{array}$ & $\begin{array}{l}\text { Continuous joints, } \\
\text { adverse orientation }\end{array}$ \\
\hline Rock friction & Rough, irregular & Undulating & Planar & $\begin{array}{l}\text { Clay infilling or } \\
\text { slickenside }\end{array}$ \\
\hline \multicolumn{5}{|l|}{ Case 2} \\
\hline Structural condition & $\begin{array}{l}\text { Few differential erosion } \\
\text { features }\end{array}$ & $\begin{array}{l}\text { Occasional differential } \\
\text { erosion features }\end{array}$ & $\begin{array}{l}\text { Many differential } \\
\text { erosion features }\end{array}$ & $\begin{array}{l}\text { Major differential } \\
\text { erosion features }\end{array}$ \\
\hline Difference in erosion rates & Small & Moderate & Large & Extreme \\
\hline Block size & $30.48 \mathrm{~cm}$ & $60.96 \mathrm{~cm}$ & $91.44 \mathrm{~cm}$ & $121.92 \mathrm{~cm}$ \\
\hline Volume of rockfall per event & $2.3 \mathrm{~m}^{3}$ & $4.6 \mathrm{~m}^{3}$ & $6.9 \mathrm{~m}^{3}$ & $9.2 \mathrm{~m}^{3}$ \\
\hline $\begin{array}{l}\text { Climate and presence of water } \\
\text { on slope }\end{array}$ & $\begin{array}{l}\text { Low to moderate } \\
\text { precipitation, no freezing } \\
\text { periods, no water on slope }\end{array}$ & $\begin{array}{l}\text { Moderate precipitation } \\
\text { or short freezing } \\
\text { periods intermittent } \\
\text { water on slope }\end{array}$ & $\begin{array}{l}\text { High precipitation or } \\
\text { long freezing periods or } \\
\text { continual water on } \\
\text { slope }\end{array}$ & $\begin{array}{l}\text { High precipitation and } \\
\text { long freezing periods or } \\
\text { continual water on } \\
\text { slope and long freezing } \\
\text { periods }\end{array}$ \\
\hline Rockfall history & Few falls & Occasional falls & Many falls & Constant falls \\
\hline
\end{tabular}

According to ODT [40] suggestion, the lower value of the decision sight distance in speed of $120 \mathrm{~km} / \mathrm{h}$ is about $340 \mathrm{~m}$. The route in the Lashotor pass is straight and no horizontal and vertical curves or obstacles exist on the road that limit sight of derivers. Therefore, actual sight distance is approximately equal to needed distance for deriver decision.

(5) Roadway width: this item defines the available maneuver room for a driver to avoid falling/fallen rock blocks. The roadway width of the Lashotor pass with respect to the highway is divided by centerline bocks, considering half whole of its width (measured from one edge of the shoulders to the centerline bocks).

(6) Geologic character: the RHRS method discussed two categories of the geological conditions which control rockfalls. Case 1 includes slopes or cuts where joints, bedding planes, or other discontinuities are 
TABLE 10: RHRS ratings for the Lashotor slopes.

\begin{tabular}{lcc}
\hline Parameter & Value & Rating \\
\hline Slope height & 34 & 100 \\
Ditch effectiveness & No catchment & 81 \\
Average vehicle risk & 450 & 100 \\
Sight distance & Adequate sit distance 100\% & 3 \\
Roadway width & $12 \mathrm{~m}$ & 6 \\
Structural condition & Continuous joints, adverse & 81 \\
Rock friction & orientation & 27 \\
Block size & Planar & 37 \\
Climate water & 0.5-1 m & 9 \\
Rockfall history & Moderate precip. & 9 \\
\hline Total score & Occasional falls & 461 \\
\hline
\end{tabular}

the dominant structural feature that control rockfalls occurrence. In this case consider continuity and orientation of joints and rock friction. Case 2 is for slopes where differential erosion and/or oversteepened slopes are the main factors that control rockfalls occurrence. Field survey and study of rockfall event that occurred in the Lashotor slopes show that the slopes are classified as case 1. Orientation, continuity, and surface condition of 253 discontinuities in the Lashotor slopes were defined.

(7) Block size or volume of rockfall per event: use of block size or volume depends on type of rockfall event that is most likely to occur. Block size should be used for individual block fall and volume should be used for rock mass fall. Based on field survey, individual blocks are typical of the rockfall in the Lashotor pass, although rock mass fall is not unexpected.

(8) Climate and presence of water on slope: presence of water and freeze/thaw cycles in addition to reducing the rock mass stability also played important role in the weathering [39]. According to the meteorological records, average of annual rainfalls in the studied area is about $122 \mathrm{~mm}$ and average of minimum temperature in December, January, and February is below zero.

(9) Rockfall history: historical information about frequency and magnitude of previous rockfall events is an excellent indicator for future expected events [20]. Except for the huge failure that occurred during the construction period, there is not any official report about rockfall occurrence in the Lashotor cut slopes. But the evidences of various rockfall events were indicated in the felid survey.

Summary explanation of RHRS parameters and ratings in the Lashotor pass is presented in Table 10.

According to this classification, slopes with a total score less than 300 are assigned a very low priority while slopes with a rating in excess of 500 are identified for urgent remedial action. As shown in Table 10, total score or RHRS value of the Lashotor pass slopes is about 461 that is near to limit of 500 and therefore remedial action is urgent.

\section{Conclusion}

Field evidence and primary survey of the Lashotor pass indicate high potentiality of slope failure in two of its rock cut slopes. Joint study and analysis of results with use of Dips and Swedge software indicate high likelihood of wedge failure, especially in the eastern slope, and toppling in the two slopes. The most significant influenced parameter in the Lashotor slopes instabilities is presence of the fault in the walls of the pass.

Based on the SMR values of slopes, the slopes rock mass is in bad class and unstable and prone to big failure. Based on SSR values and with respect to dip and high of the slopes, safety factors of both slopes are less than 1 and therefore unstable.

Also, based on this interaction matrix and the weighting coefficient of the parameters presented by KhaloKakaie and Naghadehi [26], instability indexes (IIj) of the Lashotor slopes are about 57 and classified as the unstable slopes.

Rockfall simulation in the Lashotor pass by RocFall software indicated that most of the falling rocks will reach the highway. Rockfall hazard rating system value of the Lashotor pass slopes is about 461 that emphasizes the risk of instability and the danger threatening vehicle moving there.

Based on two rock mass classification systems, SMR and SSR, probability of slope instability occurrence in the Lashotor pass is high, and based on rockfall simulation and rockfall hazard rating system occurrence of rockfall in the Lashotor pass can have very dangerous results. Therefore, the Lashotor should be classified as high-risk area.

One of the considerable problems in the Lashotor pass is exposure of shale layers in south section. Since the shale rock is weak and prone to weathering, deterioration and softening of the shale layer along the time increase the instability potential of the slopes. In addition to that long periods of exposure of carbonate rock mass to the slope face allow for the increase of weathering effects and weaken the rock mass, which result in increased possibility of dislodging of rock pieces.

Studying various methods of stabilization of the slope (advantage, limitation, and applied requirement), and with respect to the slopes conditions, reinforced shotcrete is suggested for the slopes stabilization. Shotcrete protects the rock from progressive weathering and erosions that could eventually produce unstable overhangs and increased instability potential. The reinforced shotcrete will also control the fall of small blocks of rock and increase structural support. Also simulation of rockfalls with RocFall V4 software indicated that dig of shallow ditches in two sides of the highway can trap a large number of fallen rock fragments and prevents them from arriving to the highway.

\section{Conflict of Interests}

The authors declare that there is no conflict of interests regarding the publication of this paper. 


\section{References}

[1] W. W. Lowrance, Acceptable Risk: Science and the Determination of Safety, William Kaufmann Incorporated, Los Altos, Calif, USA, 1976.

[2] ISO, "Risk management vocabulary," ISO/IEC Guide 73, International Organization for Standardization, Geneva, Switzerland, 2002.

[3] L. Pantelidis, "Rock slope stability assessment through rock mass classification systems," International Journal of Rock Mechanics and Mining Sciences, vol. 46, no. 2, pp. 315-325, 2009.

[4] Z. Bieniawski, "The geomechanics classification in rock engineering applications," in Proceedings of the 4th ISRM Congress, Montreux, Switzerland, 1979.

[5] M. Romana, "New adjustment ratings for application of Bieniawski classification to slopes," in Proceedings of the International Symposium on Role of Rock Mechanics (ISRM '85), Zacatecas, Mexico, 1985.

[6] A. Taheri and K. Tani, "Assessment of the stability of Rock slopes by the slope stability rating classification system," Rock Mechanics and Rock Engineering, vol. 43, no. 3, pp. 321-333, 2010.

[7] A. Taheri and K. Tani, "Rock slope design using Slope Stability Rating (SSR)? Application and field verifications," in Proceedings of the 1st Canada-US Rock Mechanics Symposium-Rock Mechanics Meeting Society's Challenges and Demands, Two Volume Set, pp. 215-221, Taylor \& Francis, May 2007.

[8] H. Sonmez and R. Ulusay, "Modifications to the geological strength index (GSI) and their applicability to stability of slopes," International Journal of Rock Mechanics and Mining Sciences, vol. 36, no. 6, pp. 743-760, 1999.

[9] H. Sonmez and R. Ulusay, "A discussion on the Hoek-Brown failure criterion and suggested modifications to the criterion verified by slope stability case studies," Yerbilimleri, no. 26, pp. 77-99, 2002.

[10] R. Hack, "An evaluation of slope stability classification," in Proceedings of the ISRM International Symposium on Rock Engineering for Mountainous Regions (EUROCK '02), 2002.

[11] E. Hoek and J. Bray, Rock Slope Engineering, Taylor \& Francis, London, UK, 1981.

[12] P. Budetta, "Assessment of rockfall risk along roads," Natural Hazards and Earth System Science, vol. 4, no. 1, pp. 71-81, 2004.

[13] R. Spang and T. M. Sönser, "Optimized rockfall protection by 'ROCKFALL"' in Proceedings of the 8th ISRM Congress, Tokyo, Japan, 1995.

[14] A. Ritchie, "Evaluation of rockfall and its control," Highway Research Record 17, 1963.

[15] R. Spang, "Protection against rockfall-stepchild in the design of rock slopes," in Proceedings of the 6th ISRM Congress, 1987.

[16] T. J. Pfeiffer and T. D. Bowen, "Computer simulation of rockfalls," Bulletin of the Association of Engineering Geologists, vol. 26, no. 1, pp. 135-146, 1989.

[17] J. Pfeiffer, D. Higgins, and K. Turner, "Computer aided rockfall hazard analysis," in Proceedings of 6th International Association of Engineering Geology Congress(IAEG '90), pp. 93-103, 1990.

[18] A. Azzoni and M. H. De Freitas, "Experimentally gained parameters, decisive for rock fall analysis," Rock Mechanics and Rock Engineering, vol. 28, no. 2, pp. 111-124, 1995.

[19] W. D. Stevens, RocFall, a Tool for Probabilistic Analysis, Design of Remedial Measures and Prediction of Rockfalls, Department of Civil Engineering, Master of Applied Science Graduat, University of Toronto, Toronto, Canada, 1998.
[20] L. Pierson and R. Van Vickle, "Rockfall hazard rating system participant's manual," Publication FHWA SA-93-0571993, Federal Highway Administration, Washington, DC, USA, 1992.

[21] L. Pantelidis, "A critical review of highway slope instability risk assessment systems," Bulletin of Engineering Geology and the Environment, vol. 70, no. 3, pp. 395-400, 2011.

[22] F. Guzzetti, P. Reichenbach, and S. Ghigi, "Rockfall hazard and risk assessment along a transportation corridor in the Nera valley, central Italy," Environmental Management, vol. 34, no. 2, pp. 191-208, 2004.

[23] A. Nadimi and A. Konon, "Strike-slip faulting in the central part of the Sanandaj-Sirjan Zone, Zagros Orogen, Iran," Journal of Structural Geology, vol. 40, no. 1, pp. 2-16, 2012.

[24] M.-A. Brideau, M. Yan, and D. Stead, "The role of tectonic damage and brittle rock fracture in the development of large rock slope failures," Geomorphology, vol. 103, no. 1, pp. 30-49, 2009.

[25] H. R. Pourghasemi, B. Pradhan, and C. Gokceoglu, "Application of fuzzy logic and analytical hierarchy process (AHP) to landslide susceptibility mapping at Haraz watershed, Iran," Natural Hazards, vol. 63, no. 2, pp. 965-996, 2012.

[26] R. KhaloKakaie and M. Z. Naghadehi, “The assessment of rock slope instability along the Khosh-Yeylagh Main Road (Iran) using a systems approach," Environmental Earth Sciences, vol. 67, no. 3, pp. 665-682, 2012.

[27] A. Ghazifard and A. Movahedzadeh, "Causes of landslides in the newly built road Isfahan-Shiraz," in Proceedings of the 1st Configuration Engineering Geology \& Environment, pp. 221-215, Tehran, Iran, 2000.

[28] B. Singh and R. K. Goel, Rock Mass Classification: A Practical Approach in Civil Engineering, vol. 46, Elsevier, New York, NY, USA, 1999.

[29] A. A. Nowroozi, "Empirical relations between magnitudes and fault parameters for earthquakes in Iran," Bulletin of the Seismological Society of America, vol. 75, no. 5, pp. 1327-1338, 1985.

[30] N. N. Ambraseys and C. P. Melville, A History of Persian Earthquakes, Cambridge University Press, Cambridge, UK, 2005.

[31] A. Mohajer-Ashjai and A. A. Nowroozi, "Observed and probable intensity zoning of Iran,” Tectonophysics, vol. 49, no. 3-4, pp. 149-160, 1978.

[32] Dames \& Moore International SRL, Report Seismic Studies, Investigation of Surface Faulting Proposed Medical Center, Dames \& Moore International, Tehran, Iran, 1975.

[33] M. Niazi and Y. Bozorgnia, "Behavior of near-source peak horizontal and vertical ground motions over SMART-1 array, Taiwan," Bulletin of the Seismological Society of America, vol. 81, no. 3, pp. 715-732, 1991.

[34] M. Zare, M. Ghafory-Ashtiany, and P. Bard, "Attenuation law for the strong motions in Iran," in Proceedings of the 3rd International Conference on Seismology and Earthquake Engineering SEE-3, pp. 345-355, Tehran, Iran, 1999.

[35] L. A. Pierson, S. A. Davis, and R. Van Vickle, "Rockfall Hazard rating system: implementation manual," Number FHWA-OREG-90-01, 1990.

[36] E. Hoek, C. Carranza-Torres, and B. Corkum, "Hoek-Brown failure criterion-2002 edition," in Proceedings of 5th North American Rock Mechanics Symposium and 17th Tunneling Association of Canada Conference (NARMS-TAC '02), pp. 267-273, 2002. 
[37] IIEES, "seismic hazard zonation map of Iran for the return period of 75 years," Tehran 2005, http://www.iiees.ac.ir/.

[38] Rocscience, RocFall V.4: A Statistical Analysis Program Designed to Assist with a Risk Assessment of Slopes at Risk of Rockfalls, Rocscience, Ontario, Canada, 2004.

[39] D. C. Wyllie and C. Mah, Rock Slope Engineering, Taylor \& Francis, London, UK, 2004.

[40] ODT, "Stopping sight distance and decision sight distance," Discussion Paper 8A, Oregon by The Kiewit Center for Infrastructure and Transportation, Oregon State University, Corvallis, Ore, USA, 2004. 

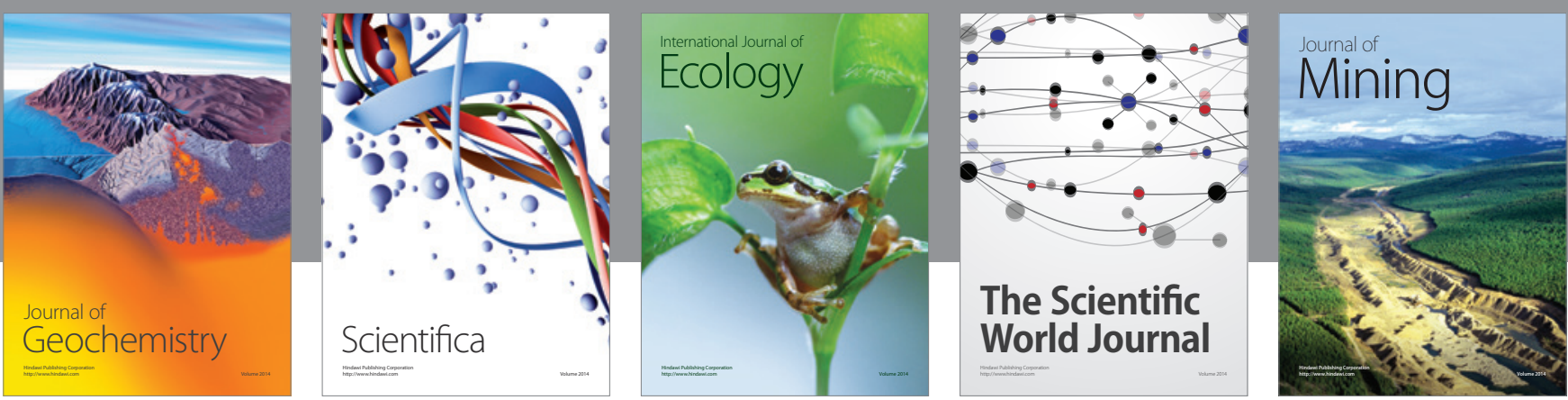

The Scientific World Journal
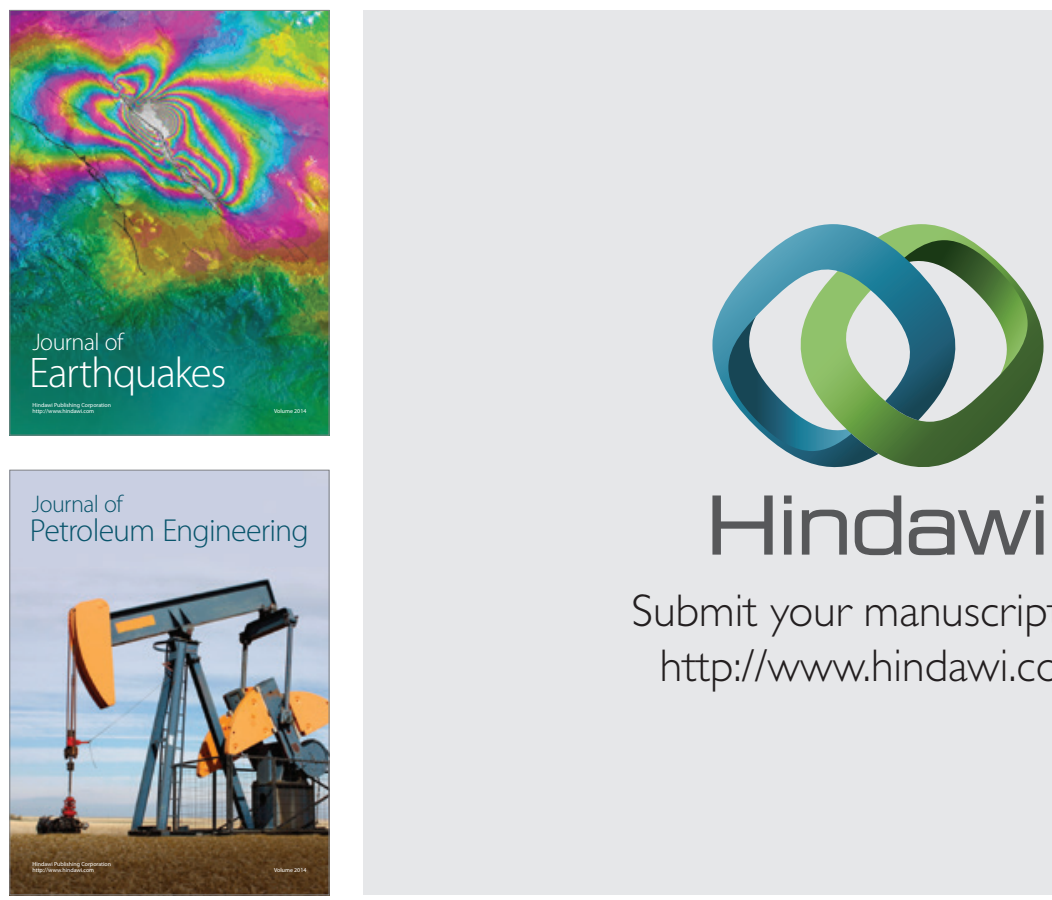

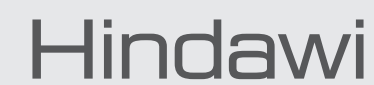

Submit your manuscripts at

http://www.hindawi.com
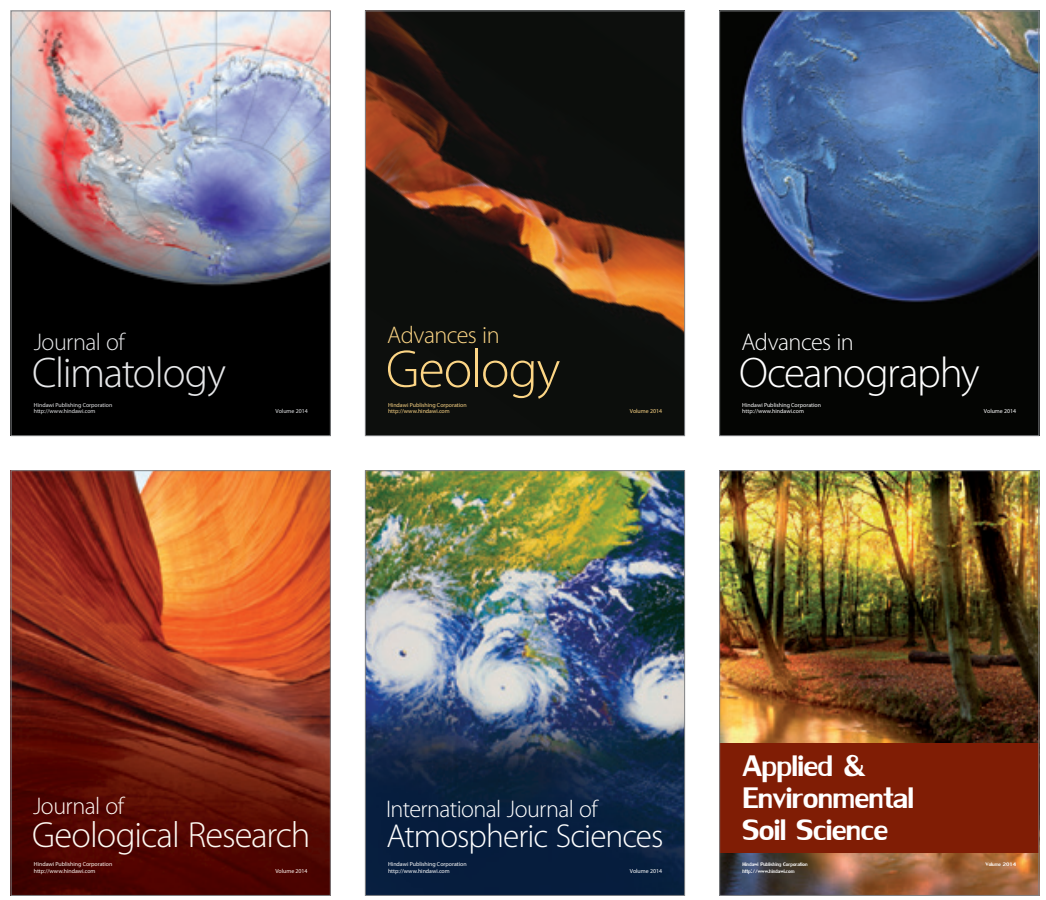
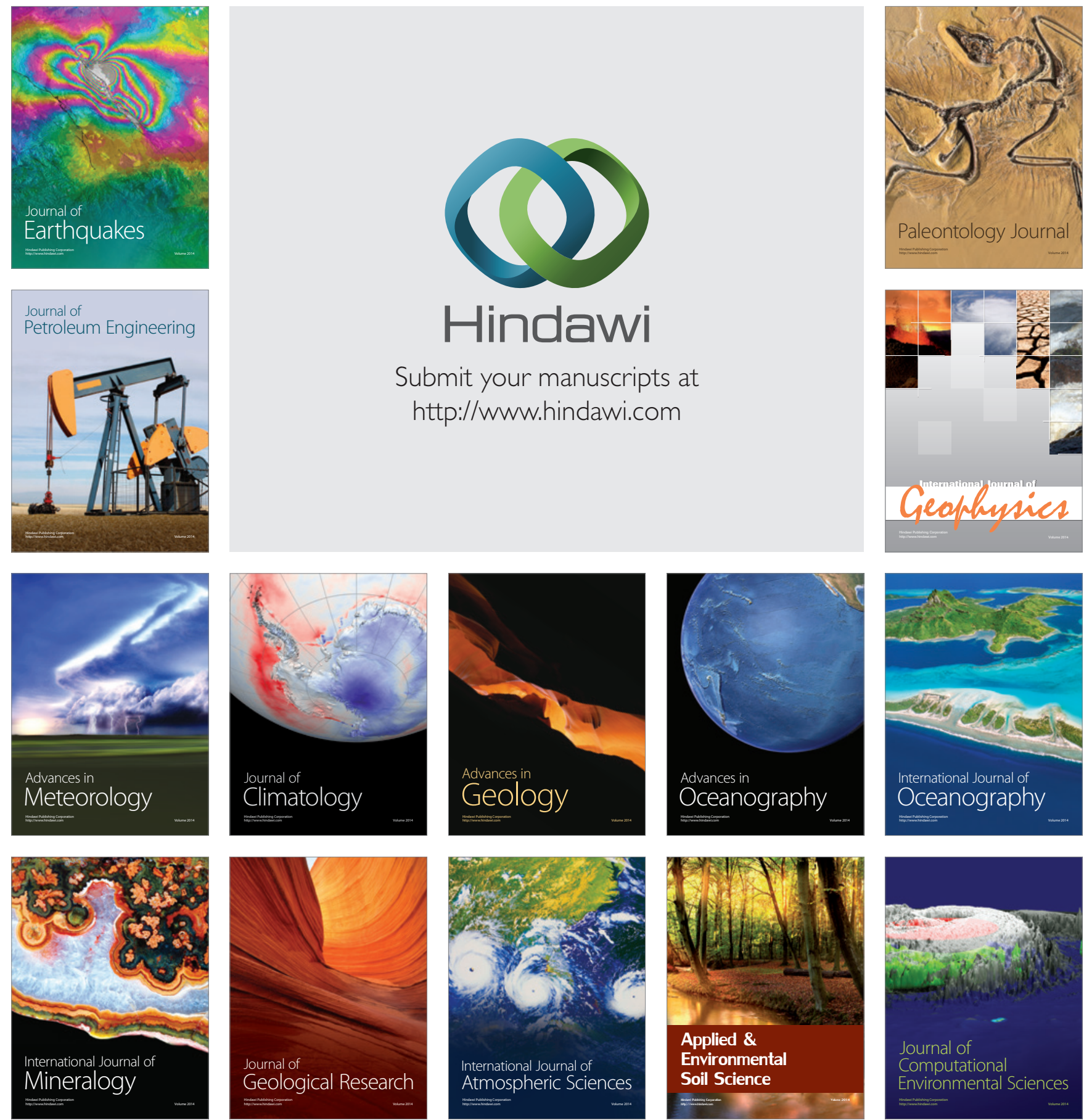